КРАСИНА Евгения Александровна - старший преподаватель кафедры английского языка факультета мировой экономики Дипломатической академии МИД России (119021, Россия, г. Москва, ул. Остоженка, 53/2, cmp. 1; lizza-sun@mail.ru)

\title{
ИТОГИ БРЕКСИТА: ГЛОБАЛЬНАЯ БРИТАНИЯ И ПРОТИВОДЕЙСТВИЕ РОССИИ
}

\begin{abstract}
Аннотация. В статье исследуются первые итоги Брексита в контексте экономических последствий и внешней политики Великобритании, ее амбициозные планы и реальное положение дел, настрой британской элиты на противостояние с Китаем и Россией в первую очередь. Приоритетом является выстраивание новых отношений со странами британского Содружества, особенно с Индией. Модернизация вооруженных сил и увеличение числа ядерных боезарядов объясняется «российской угрозой» и усилением противоракетной обороны России. Создается впечатление, что противодействие России - главный итог Брексита, т.к. информационная война с Россией началась сразу после объявления о выходе из ЕС.
\end{abstract}

Ключевые слова: Брексит, Глобальная Британия, Евросоюз и Британия, Индо-Тихоокеанский регион, Брексит и Россия

Б рексит изначально был политическим проектом, хотя в аргументах сторонников выхода было много экономических пунктов, но экономический ущерб посчитали допустимой платой за полную свободу торговли и возможность проводить самостоятельную политику. Половину всего своего внешнеторгового оборота Великобритания имеет с Евросоюзом, получает с континента 2/3 необходимого продовольствия, ее промышленность крепко связана производственными цепочками с общеевропейской. Торговое соглашение Великобритании и Евросоюза о правилах сосуществования после завершения переходного периода, подписанное под занавес 2020 г., было выработано и согласовано с большими усилиями, но показало, что все-таки стороны решили расстаться по-хорошему, без торговой войны. Британия осталась довольна сделкой из-за сохранения торговли с ЕС без пошлин и квот, а также увеличением доли вылова рыбы до 2/3 в течение 5,5 лет в британских водах. Евросоюз же сохранил в своих руках все рычаги управления доступом на рынок финансовых, консалтинговых, транспортных, юридических и других услуг, составляющих $80 \%$ британской экономики и львиную долю их экспорта в страны Евросоюза. Тут поводов для беспокойства больше у Великобритании, т.к. континент, оставляя шлагбаумы на дорогах открытыми для товаров, в торговле которыми ЕС имеет большой профицит, оставил за собой право возводить барьеры там, где имеет преимущество островная часть Европы, т.е. в оказании услуг.

Финансовые потери от Брексита с учетом заключенного соглашения оцениваются в около 100 млрд фунтов стерлингов в год при экономике в 2,6 трлн фунтов стерлингов. Это не очень существенно, но добавятся сопоставимые потери от коронакризиса, поэтому Лондону пришлось договариваться с Европой, т.к. потери без сделки были бы несравнимо выше.

Уже сейчас видны некоторые потери Британии из-за Брексита. Лондон утратил статус финансового центра Европы из-за запрета Брюсселя на торговые операции финансовых учреждений Евросоюза, а титул делового центра Европы перехватил Амстердам. За последний год Великобританию покинули 1300 тыс. чел., родившихся за ее пределами, 700 тыс. из них уехали из Лондона. Это данные Центра экономической статистики. Директор Centre For European Reform Чарльз Грант считает, что большинство британцев до сих пор не осо- 
знали, насколько жестким будет выход из Евросоюза. «Туристы, промышленность, фермеры столкнутся с утомительными формальностями на границе. Сектор услуг потеряет доступ на рынок ЕС. Пострадают компании, которые полагаются на европейских работников. И Британия потеряет привлекательность в глазах иностранных инвесторов», - сказал он ${ }^{1}$.

Зададимся вопросом, почему же Лондон озаботился суверенитетом и покинул 450-миллионный рынок, который из стоящего в очереди за кредитами МВФ «самого больного государства Европы в 1973 году» превратил Великобританию в пятую экономику мира за время членства в Евросоюзе. Ответ очевиден. Великобритании стало тесно в «дружеских» объятьях европейской бюрократии, и с помощью США ей захотелось вернуться к более значительной роли в управлении миром. Наблюдая постепенную утрату гегемонии своим союзником, Лондон решил бросить все свои силы на его поддержку и взять на себя инициативу по всяческому сдерживанию России, разжигая и поддерживая огонь русофобии в странах НАТО, особенно упирая на приграничные с Россией страны. Иногда даже кажется, что Брексит случился только для противостояния с Россией, т.к. уже во время выхода из ЕС 4 марта 2018 г. британцы инициировали скандал с отравлением Скрипалей. Министр иностранных дел Великобритании Доминик Рааб в марте 2021 г. во время кратковременного визита встретился с высокопоставленными представителями Эстонии, Латвии, Литвы, а затем министрами Дании, Финляндии, Норвегии, проведя переговоры по борьбе с COVID-19, изменению климата и, главное, по возрастающей российской угрозе. Этим блицтурне Великобритания известила весь мир о возвращении в «большую игру». О возвращении в глобальную политику говорит распространение британского влияния на украинскую элиту с целью получения рычага давления на Россию. По мнению Алексея Ильяшевича, для Глобальной Британии они (Украина и Прибалтийские республики) остаются не более чем расходным материалом. Можно давать им гарантии безопасности и забирать их обратно в случае изменения внешнеполитической конъюнктуры. Ничего личного - просто в разборках «слонов» интересы «мышей», как правило, не учитываются ${ }^{2}$.

При обсуждении ситуации вокруг Нагорного Карабаха многие видят, что за Азербайджаном стоит не столько Турция, сколько служба внешней разведки Великобритании в лице Ричарда Мура, давнего знакомого P.T. Эрдогана. «Недавно Мур посетил Анкару и, как сообщило агентство "Анадолу", на его встрече с пресс-секретарем президента Турции 11 марта 2020 года обсуждались проблемы Нагорного Карабаха, Ливии, Ближнего Востока и Восточного Средиземноморья. Есть достаточно оснований предположить, что в широком внешнеполитическом наступлении Турции большую роль играют Великобритания и лично Ричард Мур. Видимо, Лондон решил сделать Турцию тараном для продвижения своих интересов» ${ }^{3}$. Далее автор обратил внимание, что президент Украины В. Зеленский после встречи

1 Калмыков А. 2021. «ЕС добился, чего хотел». Чем закончился исторический развод Британии с Евросоюзом. 25.12.2020. Доступ: https://www.bbc.com/russian/features-55444078 (проверено 19.07.2021).

2 Ильяшевич А. 2021. Прибалтика станет расходным материалом для строительства «глобальной Британии». 11.04.2021. Доступ: https://www.rubaltic.ru/article/politika-iobshchestvo/20210311-pribaltika-stanet-raskhodnym-materialom-dlya-stroitelstva-globalnoybritanii/ (проверено 19.07.2021).

3 Карабахская война и планы британо-турецкого альянса. 15.11.2020. Доступ: https://newsfront.info/2020/11/15/karabahskaya-vojna-i-plany-britano-tureczkogo-alyansa/ (проверено 19.07.2021). 
с Ричардом Муром во время визита в Великобританию следом отправился на встречу с Р.Т. Эрдоганом. Глава МИДА Украины Д. Кулеба сказал о визите В. Зеленского в Лондон: «Мы подпишем соглашение о политическом сотрудничестве, свободной торговле и стратегическом партнерстве между нашими странами, 〈...> будем серьезно говорить о сотрудничестве в сфере безопасности». Затем многозначительно добавил: «Выйдя из ЕС, Великобритания получит большой простор для маневра, она может быть жестче в некоторых вопросах. Нам это выгодно» 1 .

В связи с выходом Британии из ЕС Лондон старается воплотить в жизнь внешнеполитический проект «Глобальная Британия». В основе проекта лежит желание нарастить торговые связи со странами, входящими в Британское Содружество, которые станут главными торговыми партнерами Лондона на мировой арене. Страны Содружества имеют исторические связи с Британией, обладают рынком 2,4 млрд чел. и 10 трлн долл. экономики. Но многие высказывают определенный скептицизм по поводу возможности разворота экономики Великобритании.

По мнению The Guardian, Лондон не смог сопоставить свои слова и амбиции со своими действиями. Даже если Британия повернется на восток от Суэца в сторону Индо-Тихоокеанского региона, «страны, расположенные за тысячу миль», не смогут «полностью компенсировать провал в торговле с Евросоюзом, в результате которого в январе Великобритания зафиксировала спад экспорта в ЕС на 5,6 млрд. фунтов стерлингов. География имеет значение» 2 .

Предложившая в 2017 г. концепцию Глобальной Британии премьер-министр Тереза Мэй делала упор на поиск новых рынков взамен европейского. Самым главным партнером должна стать Индия. Наряду с созданием зоны свободной торговли, Великобритания хочет активно участвовать в жизни Тихоокеанского региона, т.к. интересы двух стран совпадают по отношению к главному сопернику Индии - Китаю.

«Колонии не перестают быть колониями от того, что они обрели независимость», - говорил Бенджамин Дизраэли, бывший дважды премьер-министром Великобритании в XIX в. Великобритания может легче пережить Брексит за счет сохранившихся тесных связей со странами Британского Содружества. Директор международных программ Института национальной стратегии Юрий Солозобов считает, что сегодня именно у Великобритании больше всего шансов стать новой глобальной силой, опираясь на концепцию, изложенную в меморандуме Королевского объединенного института оборонных исследований, в которой говорится, что британцы - нация глобальная, прекрасно могут управлять мировыми процессами с помощью дипломатии, интриг, заговоров и создания союзов. Констатируется также конец однополярного мира - тот, кто создает коалицию, может стать глобальным лидером ${ }^{3}$. Помочь в этом должен союз с США и ЕС с созданием зоны свободной торговли по всему миру, а также модернизация армии и ядерного потенциала. Китайскому проекту «Один пояс - один путь» британцы шансов на жизнь не дают, его необходимо заблокировать, опираясь на Японию, Австралию, Индию. Также в арсенале у Лондона имеется послушная армия исламского радикализма, находящаяся под контро-

1 Шахов А. 2020. Британская база в степях Украины. Введут ли в Николаевскую область королевские войска. 7.10.2020. Доступ: https://strana.ua/news/293779-britanskaja-baza-vukraine-chto-postrojat-v-nikolaevskoj-oblasti.html (проверено 19.07.2021).

2 Глобальная Британия? 21.03.2021. Доступ: https://vpoanalytics.com/2021/03/21/ globalnaya-britaniya/ (проверено 19.04.2021)

3 Иванов А. 2020. Лондон воссоздает Британскую империю, втягивая Кремль в новую интригу. 26.12.2020. Доступ: https://svpressa.ru/politic/article/285566/ (проверено 19.07.2021). 
лем британских спецслужб, которая может помочь в блокировке Шелкового пути с помощью террористических и протестных акций по маршруту следования через мусульманские регионы.

В период утраты власти гегемоном и отсутствия многополярного мира Лондон провозгласил «мир без правил» и увидел в этом свой глобальный шанс, зная за собой, что в игре без правил ему в мире равных нет. И на это сделана ставка. Многовековой опыт дипломатии, интриг, шантажа, закулисных игр, стравливания держав, строительство теневой экономики и наркобизнеса в мировом масштабе - все это в арсенале политики Великобритании. Главное, это интересы страны. Все соглашения - без обязательств, каждый за себя. Нет неизменных союзников, есть лишь постоянные интересы. «Англичане всегда были пассионариями, а самой большой страстью было стремление к власти», - сказал канадский историк Ф. Андерхилл [Underhill 1956: 91]. Руководствуясь в своей политике принципом: «если есть партнер, который усиливается, то на него делается ставка. Если он слишком усиливается, то его надо останавливать», Великобритания ухудшила свои отношения с Китаем и ведет масштабную информационную войну, выступает инициатором санкционной экономической войны с Россией с целью сдерживания и ослабления потенциала ее развития.

Присоединение Крыма, оказание военной помощи Сирии, укрепление отношений с Китаем еще долго будут раздражителями в отношениях Запада с Россией. Необходимых России спокойных 20 лет для укрепления экономики Запад всеми силами постарается не дать. Как при помощи войны 1914 г., в разжигании которой Лондон играл первую скрипку, было остановлено развитие Российской империи, чтобы не дать стать России главной экономикой Европы, так и сейчас Великобритания преследует схожие цели.

На основании сказанного выше можно сделать следующие выводы.

1. Брексит был неизбежен, т.к. вторые роли в ЕС Британию не устраивали, а работать на благо Германии желания не было.

2. Концепция Глобальной Британии может помочь в налаживании торговых отношений и возрождении Британской империи в противовес Европейской (Евросоюзу).

3. Рейды королевского флота в Средиземноморье и в Индо-Тихоокеанский регион к побережью Китая, модернизация армии, увеличение числа ядерных боеголовок должно способствовать усилению роли Британии в НАТО, а запугивание европейских стран потенциальной угрозой агрессивных действий со стороны России может помочь Лондону усилить свое влияние в Европе.

4. Отношения с США приоритетны, т.к. позволяют Лондону оказывать значительное влияние на международные дела, особенно в «дружбе» против Китая и России. При ослаблении гегемонии США Британия готова побороться за лидерство в формировании будущего мирового порядка.

5. Экономический ущерб в 100 млрд фунтов стерлингов в год от выхода из ЕС Британия считает допустимой ценой за самостоятельность в мировой политике, но быстро растущий госдолг в 2 трлн фунтов стерлингов - самый большой за 10 лет - и спад доходов населения на 6,4\% в ближайшие 10 лет, а также несбалансированные торговые отношения с Европой могут внести большие коррективы в амбициозные планы.

6. Россию намеренно обвиняют в отравлениях, в агрессивном поведении, в желании напасть на Великобританию, чтобы самим вести против России враждебные действия. Чем дальше, тем абсурднее становятся обвинения России Западом. В них уже перестает присутствовать здравый смысл. По сообщению телеканала РБК со ссылкой на газету The Times, британские власти в мае 2021 г. 
собираются ввести закон для защиты от «враждебных государств», таких как Россия и Китай 1 .

\section{Список литературы}

Underhill F.H. 1956. The British Commonwealth. An Experiment in Co-operation among Nations. Durham, N.C.: Duke University Press. xxiii +127 p.

KRASINA Evgeniya Aleksandrovna, Senior Lecturer of the Chair of English Language, Faculty of World Economy, Diplomatic Academy of the Ministry of Foreign Affairs of Russia (bld. 1, 53/2 Ostozhenka St, Moscow, Russia, 119021; lizza-sun@mail.ru)

\section{BREXIT OUTCOMES: GLOBAL BRITAIN AND OPPOSITION TO RUSSIA}

Abstract. The article analyzes the first results of Brexit in the context of the economic consequences and the UK foreign policy, its ambitious plans and the real state of affairs, the predisposition of the British elite to confront China and Russia in the first place. The priority is to build new relationships with the countries of the British Commonwealth, especially with India. The modernization of the armed forces and the increase in nuclear warheads are attributed to the Russian threat and the strengthening of Russia's missile defense. One gets the impression that the opposition to Russia is the main outcome of Brexit, since the information war with Russia began immediately after the announcement of its withdrawal from the EU. Keywords: Brexit, Global Britain, European Union and Britain, Indo-Pacific, Brexit and Russia

1 Swinford S., Courea E. 2021. New powers to kick out spies from hostile states as concerns mount over Russia and China. - The Times. 19.04.2021. URL: https://www.thetimes.co.uk/article/new-powers-to-kickout-spies-from-hostile-states-as-concerns-mount-over-russia-and-china-zqfsxdjv9 (accessed 19.07.2021). 